\title{
Molecular Identification Keys for Cultivars and Lines of Cornus florida and C. kousa Based on Simple Sequence Repeat Loci
}

\author{
Phillip A. Wadl' ${ }^{1}$ Xinwang Wang ${ }^{1}$, Andrew N. Trigiano, John A. Skinner, Mark T. Windham, \\ and Robert N. Trigiano ${ }^{2}$ \\ Department of Entomology and Plant Pathology, University of Tennessee, 205 Ellington Hall, 2431 \\ Joe Johnson Drive, Knoxville, TN 37996-4560
}

\author{
Timothy A. Rinehart \\ USDA-ARS Thad Cochran Southern Horticultural Laboratory, 810 Highway 26 West, Poplarville, MS \\ 39470
}

\author{
Sandra M. Reed \\ USDA-ARS Floral and Nursery Plants Research Unit, U.S. National Arboretum, Tennessee State \\ University Nursery Research Center, 472 Cadillac Lane, McMinnville, TN 37110
}

\begin{abstract}
Vincent R. Pantalone
Department of Plant Sciences, University of Tennessee, 2431 Joe Johnson Drive, Knoxville, TN 37996-4561
\end{abstract}

\begin{abstract}
ADDITIONAL INDEX wORDs. SSR, allele sharing distance, principal coordinate analysis, flowering dogwood
Abstract. Flowering dogwood (Cornus florida) and kousa dogwood (C. kousa) are popular ornamental species commonly used in the horticultural industry. Both trees are valued for their beautiful floral display and four-season appeal. Species-specific simple sequence repeat (SSR) loci were used to genotype and assess genetic diversity of 24 flowering dogwood cultivars and breeding lines and 22 kousa dogwood cultivars. Genetic diversity was determined by allele sharing distances and principal coordinate analysis and was high in both species. Molecular identification keys were developed for cultivars and breeding lines of each species using a few polymorphic SSRs loci (four in $C$. florida and five in C. kousa). Most (18 of 24) of the flowering dogwood and all (22 of 22) kousa dogwood accessions could be distinguished from each other using these SSRs; those that could not were resolved using DNA amplification fingerprinting. The reliability of both keys was assessed using five anonymous cultivars for each dogwood species, which were correctly identified using the molecular keys. The genetic information presented here will be useful for identification and verification of cultivars for nurseries and as molecular markers for breeders and researchers.
\end{abstract}

The U.S. Department of Agriculture Nursery Crops 2006 Summary (USDA, 2007) estimated that total nursery crop sales in the United States exceeded $\$ 4.5$ billion that year, which represented an increase of $17 \%$ during the previous 3 years. Deciduous flowering trees accounted for over $\$ 300$ million of total nursery sales (USDA, 2007). Some of the types of trees included in the deciduous flowering trees category were crabapple (Malus spp.), crape myrtle (Lagerstroemia spp.), dogwood (Cornus spp.), ornamental pear (Pyrus calleryana), and redbud (Cercis spp.). Unfortunately, the Nursery Crops 2006 Summary does not provide estimates for total sales for individual crops classified in the deciduous flowering trees category. However, total sales of individual nursery crop sales can be obtained from the 1998 Census of Horticultural Specialties (USDA, 1998), and according to this survey, dog-

Received for publication 14 July 2008. Accepted for publication 19 Sept. 2008. This work was supported by USDA Agreement No. 58-6404-2-0057 and the J. Frank Schmidt Family Charitable Foundation.

Mention of trade names or commercial products in this article is solely for the purpose of providing specific information and does not imply recommendation or endorsement by the University of Tennessee or the U.S. Department of Agriculture.

${ }^{1}$ Equal work was completed by these two authors.

${ }^{2}$ Corresponding author. E-mail: rtrigian@utk.edu. woods accounted for over $\$ 26$ million in sales $(\approx 8 \%$ of total sales) within the deciduous flowering trees category. Consequently, the 1998 Census of Horticultural Specialties concluded that dogwood sales are important to retail and wholesale nurseries, particularly in eight states (Alabama, California, Illinois, North Carolina, New Jersey, Oregon, Tennessee, Virginia) that accounted for $74.9 \%$ of dogwood trees sold in the United States.

The genus Cornus contains 55 species of trees, shrubs, and herbs that are widely distributed throughout the northern hemisphere, with two species endemic to South America (Fan and Xiang, 2001). Two of these species, C. florida and C. kousa, are the most popular in the ornamental horticulture industry, although other species such as $C$. nuttallii, C. angustata, $C$. mas, and C. sericea are often used in landscapes. With over 100 named cultivars, flowering dogwood is one of the most common ornamental trees in the eastern United States. and is valued for its pink, red, or white bracts; bright red fall foliage; and the production of bright red berries (Cappiello and Shadow, 2005). Although the bracts of kousa dogwood are typically not as showy as those of flowering dogwood, kousa dogwood has other appealing attributes such as dark green foliage, bright red fall color, vivid red-colored aggregate fruit, and attractive form (Dirr, 1998). Additionally, kousa dogwoods are regarded as 
more resistant to dogwood anthracnose (Discula destructiva) and powdery mildew (Erysiphe pulchra) than flowering dogwood (Hagan et al., 2001; Ranney et al., 1995). Kousa dogwood is considered to be the Asian counterpart of the native North American flowering dogwood (Cappiello and Shadow, 2005). Over 100 cultivars of kousa dogwoods exist with bract colors ranging from white to cream and from red to pink (Cappiello and Shadow, 2005) and a few have unique leaf qualities and vegetative habits. Kousa dogwood usually blooms $\approx 1$ month later than flowering dogwood.

Inflorescence characteristics are useful for identifying cultivars within each species; however, these traits are only visible for a short period in the spring. Vegetative phenotypes of either flowering or kousa dogwood cultivars are very similar and unless there is some distinguishing somatic trait such as variegated or colored leaves, it is nearly impossible to distinguish one cultivar from another at times other than when the trees are in flower. Lack of obvious differences between phenotypes increases the probability of mislabeling, multiple releases of the same cultivar under different names, and misappropriation and misrepresentation of cultivars by third parties (Smith et al., 2007; Trigiano et al., 2004).

Most woody plant cultivars, including dogwoods, are vegetatively propagated, and new cultivars are obtained from the following two principal sources: conventional breeding and selection of spontaneous or induced variations of existing cultivars. Molecular markers can reliably identify clones, breeding lines, hybrids, and cultivars (Winter et al., 2002). Using molecular markers, analysis of the genetic constitution of plants can be determined at an early stage, enabling the plant breeder to decrease the time and cost required for selection. Molecular marker development has been almost exclusively limited to agronomic and forestry crops. Most ornamental molecular marker research has been directed toward cultivar identification (Arus, 2000). For dogwood, the use of molecular markers has been used primarily in hybrid and cultivar detection (Ament et al., 2000; Caetano-Anollés et al., 1999; Smith et al., 2007; Trigiano et al., 2004; Windham and Trigiano, 1998).

Microsatellites or simple sequence repeats (SSRs) are stretches of DNA that consist of tandemly repeated mono-, di-, tri, tetra-, or penta-nucleotide units that occur in abundance in the genomes of most eukaryotes (Powell et al., 1996). SSRs are the preferred markers in plant breeding as a result of their uniform genome coverage, high levels of polymorphism, codominance, and reproducibility (Pejic et al., 1998). Although SSR discovery and development is initially more time-consuming and expensive than amplified fragment length polymorphisms (AFLPs) and other DNA characterization methods, SSRs provide more efficient tools that can be used to assess parentage among breeding populations, identify similar cultivars, determine genetic diversity, and resolve plant patent issues.

In this study, SSRs were used to determine the genetic diversity and relatedness between 24 cultivars and breeding lines of $C$. florida and 22 selected cultivars of $C$. kousa. Additionally, a molecular key was constructed from speciesspecific SSR loci to distinguish most of these popular cultivars and breeding lines of both species.

\section{Materials and Methods}

Plant material and DNA extraction. Twenty-four flowering dogwood cultivars and breeding lines and 22 kousa dogwood cultivars were selected for analysis (Table 1). Unopened flower buds or emerging leaves, which were not fully expanded, were collected and stored at $-80{ }^{\circ} \mathrm{C}$ until genomic DNA was extracted. Samples were ground in liquid nitrogen and DNA extracted using the Qiagen DNeasy Plant DNA isolation kit (Qiagen, Valencia, CA). DNA was quantified with the NanoDrop ${ }^{\circledR}$ ND-1000 ultraviolet-Vis Spectrophotometer (NanoDrop Technologies, Wilmington, DE); DNA quality was determined using $2 \%$ agarose gels stained with ethidium bromide and visualized in the 2000 Gel Documentation System (Bio-Rad Laboratories, Hercules, CA).

Simple SEQUENCE REPEAT PRIMER SCREENING, POLYMERASE CHAIN REACTION AMPLIFICATION, AND DNA AMPLIFICATION FINGERPRINTING OF CULTIVARS NOT RESOLVED USING SIMPLE SEQUENCE REPEATS. Primer pairs from 311 C. florida SSR loci (Wang et al., 2008) and 86 C. kousa SSR loci (Wadl et al., 2008) were initially selected and screened against two cultivars each of C. florida (Appalachian Spring and Cherokee Brave) and C. kousa (Blue Shadow and Galilean) to determine optimum polymerase chain reaction (PCR) conditions. Seventeen C. florida SSR loci (Table 2) were then chosen for genotyping 24 C. florida cultivars and breeding lines (Table 1) and 13 C. kousa SSR loci (Table 2) were selected for genotyping 22 C. kousa cultivars (Table 1). Cornus florida SSR amplification was completed using the following conditions: $10 \mu \mathrm{L}$ PCR reactions contained $0.4 \mathrm{ng}$ genomic DNA, $2.5 \mathrm{~mm} \mathrm{MgCl} 2,1 \times$ GeneAmp PCR Buffer II (Applied Biosystems, Foster City, CA), $0.2 \mathrm{~mm}$ dNTPs, $0.25 \mu \mathrm{M}$ primer, $0.6 \mathrm{U}$ AmpliTaq Gold ${ }^{\circledR}$ DNA polymerase (Applied Biosystems), and sterile, distilled water. Cycling conditions were as follows: 1 cycle of $94^{\circ} \mathrm{C}$ for $5 \mathrm{~min} ; 35$ cycles of $94^{\circ} \mathrm{C}$ for $40 \mathrm{~s}, 55^{\circ} \mathrm{C}$ for $40 \mathrm{~s}, 72^{\circ} \mathrm{C}$ for $30 \mathrm{~s}$; and one cycle of $72{ }^{\circ} \mathrm{C}$ for $4 \mathrm{~min}$. C. kousa SSR amplification

Table 1. Cornus florida cultivars and breeding lines and C. kousa cultivars used for simple sequence repeat ${ }^{\mathrm{z}}$.

\begin{tabular}{ll}
\hline C. florida samples (code) & C. kousa samples (code) \\
\hline Appalachian Blush (AB) & Autumn Rose (AR) \\
Appalachian Joy (AJ) & Beni Fuji (BF) \\
Appalachian Mist (AM) & Big Apple (BA) \\
Appalachian Morning (AMN) & Blue Shadow (BS) \\
Appalachian Spring (AS) & Bodnant (B) \\
Appalachian Snow (ASN) & Bush's Pink (BP) \\
Cherokee Brave (CB) & Doubloon (D) \\
Cherokee Chief (CC) & Elizabeth Lustgarten (EL) \\
Cherokee Daybreak (CD) & Emerald Star (ES) \\
Cherokee Princess (CP) & Galilean (G) \\
Cherokee Sunset (CS) & Greensleeves (GS) \\
Cloud 9 (C9) & Milky Way (MW) \\
Fragrant Cloud (FC) & Milky Way Select (MWS) \\
Little Princess (LP) & Miss Satomi (MS) \\
Plena (P) & National (N) \\
Presidential (PB) & Rochester (R) \\
Pygmy (PY) & Snow Flake (SF) \\
Red Pygmy (RP) & Spinners (SP) \\
World's Fair (WF) & Steeple (ST) \\
Line 94-60 (L9460) & Summer Majesty (SM) \\
Line 94-83 (L9483) & Temple Jewel (TJ) \\
Line 95-04 (L9504) & Trinity Star (TS) \\
Line 95-25 (L9525) &
\end{tabular}

Line 95-25 (L9525)

Line 95-28 (L9528)

${ }^{\mathrm{z}}$ Code indicates labeling of cultivars in figures. 
Table 2. Simple sequence repeat (SSR) loci used in the analysis of 24 Cornus florida cultivars and breeding lines and 22 C. kousa cultivars.

\begin{tabular}{|c|c|c|c|c|c|}
\hline Locus $^{\mathrm{z}}$ & $\begin{array}{c}\text { GenBank } \\
\text { accession no. }\end{array}$ & Repeat & $\begin{array}{l}\text { Expected allele } \\
\text { size and actual } \\
\text { range }^{y}(\mathrm{bp})\end{array}$ & $\begin{array}{l}\text { Alleles } \\
\text { (no.) }\end{array}$ & Primer sequence \\
\hline \multirow[t]{2}{*}{$\overline{\mathrm{CF} 150}$} & ED651823 & $(\mathrm{AC})_{9}$ & $141(132-148)$ & 6 & F: TGCAATATCTACATAGTCGATACACACA \\
\hline & & & & & R: TTAGGGATGTTTGTGCCTTGTTAG \\
\hline \multirow[t]{2}{*}{ CF191 } & ED651856 & $(\mathrm{AG})_{20} \mathrm{~T}(\mathrm{GA})_{12}(\mathrm{GAA})_{4}$ & $181(126-196)$ & 18 & F: AACCTGCATCTTCCCCAAGT \\
\hline & & & & & R: CCTTTTACCAACCCAACACG \\
\hline \multirow[t]{2}{*}{$\mathrm{CF} 213^{\mathrm{x}}$} & ED651874 & $(\mathrm{CT})_{9}(\mathrm{GT})_{12}$ & $129(122-174)$ & 16 & F: TGCAAATGGTTATTGATTGCTCTC \\
\hline & & & & & R: ATTTGTTTCCCATGACCTGAAAGA \\
\hline \multirow[t]{2}{*}{ CF273 } & ED651920 & $(\mathrm{AC})_{14}$ & $135(122-144)$ & 8 & F: TCATATTTATGCTTTCCTTGCCGT \\
\hline & & & & & R: GTGATCCTCTCCTAACGACTTCCA \\
\hline \multirow[t]{2}{*}{ CF322 } & ED651957 & $(\mathrm{AG})_{20} \mathrm{TG}(\mathrm{AG})_{12}$ & $180(128-172)$ & 12 & F: CTAACCTGCATCTTCCCCAAG \\
\hline & & & & & R: TTTACCAACCCAACACGACAC \\
\hline \multirow[t]{2}{*}{ CF479 } & ER870501 & $(\mathrm{AC})_{25}$ & $160(160-180)$ & 7 & F: GTACTGGCGTGATCGAGTAT \\
\hline & & & & & R: TGTGATTGTAATATTGAAATGGAT \\
\hline \multirow[t]{2}{*}{ CF562 } & ER870584 & $(\mathrm{GT})_{16}$ & $204(190-222)$ & 5 & F: CCAGAGGTATGAATTCTGTGT \\
\hline & & & & & R: CTTGCAAATTGTTGTAATGAA \\
\hline \multirow[t]{2}{*}{ CF581 ${ }^{\mathrm{x}}$} & ER870603 & $(\mathrm{GT})_{6}(\mathrm{GT})_{5}(\mathrm{TG})_{9}$ & $145(217-241)$ & 5 & F: GGGGCAGTAAGAAAACACATTC \\
\hline & & & & & R: TGTAACCTGCACATAGACAGCA \\
\hline \multirow[t]{2}{*}{ CF585 ${ }^{\mathrm{x}}$} & ER870607 & $(\mathrm{AT})_{7}(\mathrm{GT})_{11}$ & $163(160-184)$ & 10 & F: AACGAAGCAAGCAAAACAATC \\
\hline & & & & & R: ACCCCACCACTTCATCTCTCT \\
\hline \multirow[t]{2}{*}{ CF597 ${ }^{\mathrm{x}}$} & ER870619 & $(\mathrm{AC})_{13}$ & $107(90-122)$ & 9 & F: AAGTCAGATCATTTCAGATTAACA \\
\hline & & & & & R: CGAATTGACGATAAATACAAAATA \\
\hline \multirow[t]{2}{*}{ CF615 } & ER870637 & $(\mathrm{TG})_{12}$ & $152(134-157)$ & 8 & F: ATTTATGAACCCTTTCAACTGT \\
\hline & & & & & R: TCACACTCTCTATCTTCATCTTTC \\
\hline \multirow[t]{2}{*}{ CF633 } & ER870655 & $(\mathrm{AC})_{12}$ & $151(139-150)$ & 4 & F: AACTAGATTCAAACATTATCCСТC \\
\hline & & & & & R: CCATTGATCAGTCATCCTATTAT \\
\hline \multirow[t]{2}{*}{ CF634 } & ER870656 & $(\mathrm{AG})_{14}$ & $109(96-120)$ & 11 & F: GAAATTCAAATTTTAAAGAAGTCC \\
\hline & & & & & R: TTGTATAGTACTTCAAGGCCACT \\
\hline \multirow[t]{2}{*}{ CF641 } & ER870663 & $(\mathrm{AG})_{14}$ & $119(111-126)$ & 3 & F: ATACGTACTATACCATGCACATTT \\
\hline & & & & & R: ACCTATCTATACAATTTTCTTCGC \\
\hline \multirow[t]{2}{*}{ CF646 } & ER870668 & $(\mathrm{AG})_{24}$ & $157(109-125)$ & 7 & F: ACTCATTCTTCCCAGTTTACAT \\
\hline & & & & & R: TCCACTGACTGAGAAAGTAAATAA \\
\hline \multirow[t]{2}{*}{ CF701 } & ER870723 & $(\mathrm{CT})_{19}$ & $136(115-132)$ & 7 & F: GTACCAACCTCTCTAACAGAAAAT \\
\hline & & & & & R: TTTCTGAGAGATCTTGATTCTTG \\
\hline \multirow[t]{2}{*}{ CF713 } & ER870735 & $(\mathrm{TC})_{18}$ & $152(108-123)$ & 5 & F: GATACTTATGCAATTAGGACACAA \\
\hline & & & & & R: GTAACAATGGTGGAAGGAAG \\
\hline \multirow[t]{2}{*}{ CK005 } & EU544308 & $(\mathrm{AC})_{20}$ & $249(221-251)$ & 9 & F: GCATTTGTCCTTTGTTTGACAT \\
\hline & & & & & R: TTTTTCGCGAAGTGTTCTCTAC \\
\hline CK007 & EU125522 & $(\mathrm{AG})_{8}$ & $110(109-111)$ & 3 & F:GAGCCCAGAAGAAGAATATAGAC \\
\hline & & & & & R:ATATAATTGGGTTGGGTTTTG \\
\hline $\mathrm{CK} 015^{\mathrm{x}}$ & EU125523 & $(\mathrm{CT})_{10}$ & $109(104-133)$ & 17 & F:GTCAAATTTTTGATCTTTCTCTCT \\
\hline & & & & & R:GGAGAGACAGAGTACAGTAGAGGT \\
\hline CK029 & EU125524 & $(\mathrm{TC})_{8}$ & $107(85-107)$ & 7 & F:AATTTAGGTTAAGGTTTTGATTTG \\
\hline & & & & & R:AGAGAGAATAGGTTACAGCATCAT \\
\hline CK031 & EU125525 & $(\mathrm{CT})_{7}$ & $138(114-137)$ & 7 & F:TGTCACTGCTTACAGAAACAAT \\
\hline & & & & & R:TATGACGAGATTGTATAAGTTGCT \\
\hline CK040 & EU125526 & $(\mathrm{GT})_{16}$ & $93(80-107)$ & 10 & F:CCAAGTCAGTTTGGTAGTAATTC \\
\hline & & & & & R:AGTGCAACTTTTACTTGCTATGT \\
\hline CK043 & EU125527 & $(\mathrm{AT})_{6}$ & $112(112-126)$ & 4 & F:TTGAGACCCTCTTCATAGTCTAGT \\
\hline & & & & & R:CTACAATCCTAAACAGCTAAACAA \\
\hline CK047 & EU125528 & $(\mathrm{AC})_{6}$ & $126(128-134)$ & 6 & F:GAAAGAGATAAAAGATGGTTCAAT \\
\hline & & & & & R:CTTATAGAGTAAGCCCACCATC \\
\hline CK048 & EU125529 & $(\mathrm{TA})_{6}$ & $145(151-179)$ & 11 & F:ACCAACCAAAAGAAGTATAAAGAA \\
\hline & & & & & R:CCTATAAATAAGGAGTGATTTGGT \\
\hline CK058 & EU544309 & $(\mathrm{GT})_{10}$ & $147(146-184)$ & 12 & F: CTTAAGTCACAAAGACAATGAAAT \\
\hline & & & & & R: AAGAGAGTTCAGATTTATCTTTGC \\
\hline CK070 & EU544310 & $(\mathrm{GT})_{9}$ & $120(116-120)$ & 4 & F: CTTTTCTACACССТTAACAAGTG \\
\hline & & & & & R: TAGACAATATGTGCTTAATTGGTT \\
\hline
\end{tabular}


Table 2. Continued.

\begin{tabular}{|c|c|c|c|c|c|}
\hline Locus $^{z}$ & $\begin{array}{c}\text { GenBank } \\
\text { accession no. }\end{array}$ & Repeat & $\begin{array}{l}\text { Expected allele } \\
\text { size and actual } \\
\text { range }^{\mathrm{y}}(\mathrm{bp})\end{array}$ & $\begin{array}{l}\text { Alleles } \\
\text { (no.) }\end{array}$ & Primer sequence \\
\hline$\overline{\mathrm{CK} 071}$ & EU544311 & $(\mathrm{TG})_{9}$ & $120(114-133)$ & 6 & $\begin{array}{l}\text { F: CTGCTCGGTTAAGGTATGTT } \\
\text { R: TTTAAAGTGCGTTGTATACATAAAT }\end{array}$ \\
\hline $\mathrm{CK} 072^{\mathrm{y}}$ & EU544312 & $(\mathrm{GT})_{10}$ & $122(102-134)$ & 6 & $\begin{array}{l}\text { F: AGCACTCATAGTCCTTGCAC } \\
\text { R: GTTAAAACGAAGAAGATACAACAA }\end{array}$ \\
\hline
\end{tabular}

${ }^{\mathrm{z} S S R}$ loci designated CF were isolated from C. florida (Wang et al., 2008) and SSR loci designated CK were isolated from C. kousa (Wadl et al., 2008).

${ }^{y}$ Allele size range indicated in parentheses. Exact basepair (bp) allele estimates were determined by averaging the results of three replicates per sample with all loci analyzed and exact basepair estimates of allele size were used for creating the shared allele distance matrix.

${ }^{x}$ Loci used to develop molecular key for flowering dogwood and kousa dogwood.

was completed using the same components listed for $C$. florida except that $0.5 \mu \mathrm{M}$ primer and $0.8 \mathrm{U}$ AmpliTaq Gold ${ }^{\circledR}$ DNA polymerase were used. Cycling conditions were as follows: one cycle of $94{ }^{\circ} \mathrm{C}$ for $5 \mathrm{~min} ; 35$ cycles of $94{ }^{\circ} \mathrm{C}$ for $40 \mathrm{~s}, 58^{\circ} \mathrm{C}$ for $40 \mathrm{~s}, 72{ }^{\circ} \mathrm{C}$ for $30 \mathrm{~s}$; and one cycle of $72{ }^{\circ} \mathrm{C}$ for $4 \mathrm{~min}$. PCR products were sized on the HDA-GT12 ${ }^{\mathrm{TM}}$ Capillary Electrophoresis System [eGene (Qiagen)] using an internal 25-basepair (bp) DNA stepladder. All loci were screened three times per sample for reproducibility and to ensure adequate intensity of DNA products.

Genomic DNA from three specimens of each flowering dogwood 'World's Fair', 'Cloud 9', 'Appalachian Joy', 'Appalachian Spring', and 'Fragrant Cloud' were analyzed using DNA amplification fingerprinting (DAF) (Caetano-Anollés et al., 1991; Trigiano and Caetano-Anollés, 1998), which arbitrarily samples a greater proportion of the genome than SSRs. Although this technique does not identify specific loci as SSRs do, it does have the potential to discern differences between cultivars and breeding lines that appear identical to each other using SSR markers (Windham and Trigiano, 1998). The following four octomer primers were used to amplify DNA: (5'-3'): GTA ACG CC, GTA TCG CC, GAG CCT GT, and CCT GTG AG. The $20 \mu \mathrm{L}$ reaction mixtures consisted of 2 ng DNA, $1 \times$ Stoffel buffer, $2.5 \mathrm{~mm} \mathrm{MgCl}_{2}, 200 \mu \mathrm{M}$ dNTPs, $3 \mu \mathrm{M}$ primer, and $4 \mathrm{U}$ of AmpliTaq ${ }^{\circledR}$ DNA Polymerase Stoffel Fragment enzyme (Applied Biosystems) and were amplified using the following program: $95^{\circ} \mathrm{C}$ for $30 \mathrm{~s}, 30^{\circ} \mathrm{C}$ for $30 \mathrm{~s}$, and $72^{\circ} \mathrm{C}$ for $30 \mathrm{~s}$. A total of 35 cycles was completed. Products were separated on $10 \%$ polyacrylamide gels and stained with silver (Bassam et al., 1991). Binary data (presence $=1$ and absence $=0$ ) were collected and a similarity index developed using Jaccard constant and NTSYS software (Rohlf, 1992).

SiMPLE SEQUENCE REPEAT GENOTYPING AND DATA ANALYSIS. Data from 17 C. florida SSR loci and 13 C. kousa SSR loci were analyzed separately with POPULATIONS version 1.2.28 (Langella, 2002) to estimate the shared allele distance (Jin and Chakraborty, 1994) and create individual distance matrices for the $C$. florida and the $C$. kousa cultivars and breeding lines, respectively. Principal coordinate analysis (PCA) plots were produced from the shared allele distance matrix using NTSYS software. A molecular key was developed respectively from genotyping the $C$. florida cultivars and breeding lines and the C. kousa cultivars. Four polymorphic SSR loci were used to develop a molecular key for $C$. florida and six polymorphic SSR loci were used to develop a molecular key for C. kousa (Table 2). Microsatellite analyses were conducted using eGene as described previously. For molecular key development for flowering dogwood cultivars and breeding lines, SSR locus CF581 was used first to separate the samples into four groups and the other SSR loci were used to further delineate the groups until each sample was uniquely identified. For molecular key development of the kousa dogwood cultivars, SSR locus CK058 was used first to separate the samples into four groups and the other SSR loci were used to further separate the groups until each sample was uniquely identified. For both keys, a conservative \pm 2 - to 3-bp allele size determination error range was used to develop a key that allows for reproducibility between other laboratories. $\mathrm{A} \pm 2$ - to 3-bp error range for allele size determination was used because of a 2-bp resolution when analyzing samples on eGene and allele size determination for eGene software is based on regression analysis. This error range was used in the initial separation of all cultivars and breeding lines for both molecular keys. After initial separation of samples using the appropriate loci, exact basepair estimates of allele size were used for further separation of samples. The exact basepair allele estimates were determined by averaging the results of three replicates per sample with all loci analyzed. These basepair estimates of allele size were used for creating the shared allele distance matrix and the PCA plots. Five anonymous flowering and kousa dogwood samples each were selected by R. N. Trigiano and were analyzed to test the validity of the molecular keys.

\section{Results}

All 17 SSR loci from C. florida were polymorphic and amplified successfully when tested on cultivars and breeding lines of flowering dogwood. In total, 141 alleles were detected with a range of three to 18 per locus (Table 2). The allele sharing distance matrix and PCA for flowering dogwood demonstrated high genetic diversity for the loci analyzed. Allele sharing distances ranged from 0.44 to 0.94 and most of the values were greater than 0.70 (Table 3). Principal coordinate analysis based on allele sharing distances accounted for $27.6 \%$ of the total variation (Fig. 1) and no clusters of cultivars were discernible. Four loci (CF213, CF581, CF585, and CF597) were used to develop a molecular key that successfully separated 18 of 24 flowering dogwood cultivars and breeding lines (Fig. 2). The six cultivars (three pairs) that could not be separated using SSRs were Appalachian Spring and Presidential, Cherokee Brave and Cherokee Chief, and Cloud 9 and World's Fair. DAF could not distinguish 'Cloud 9' from 'World's Fair'; all loci were identical (Table 4). The other two cultivar pairs were not evaluated with DAF in this study. 


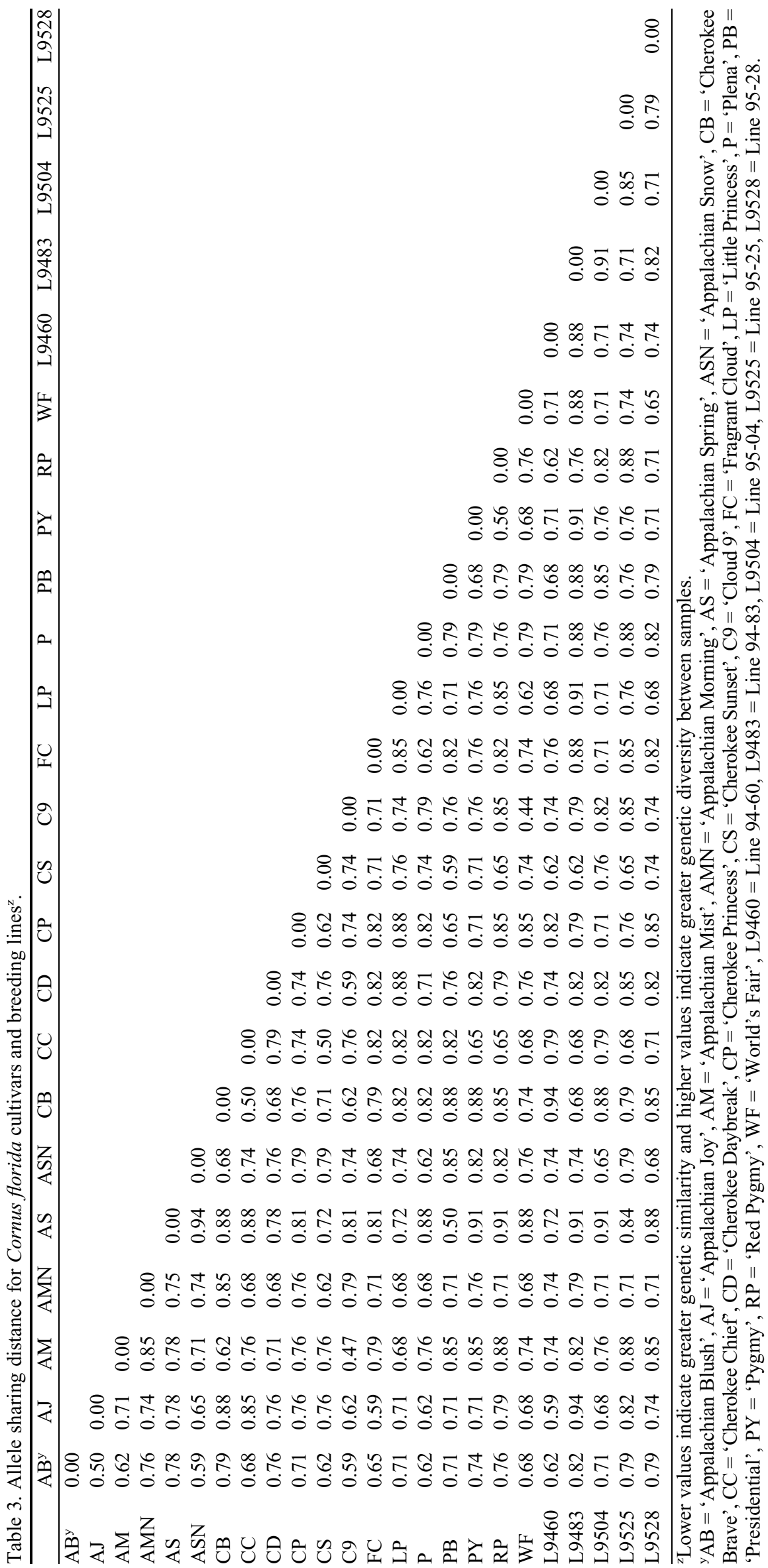




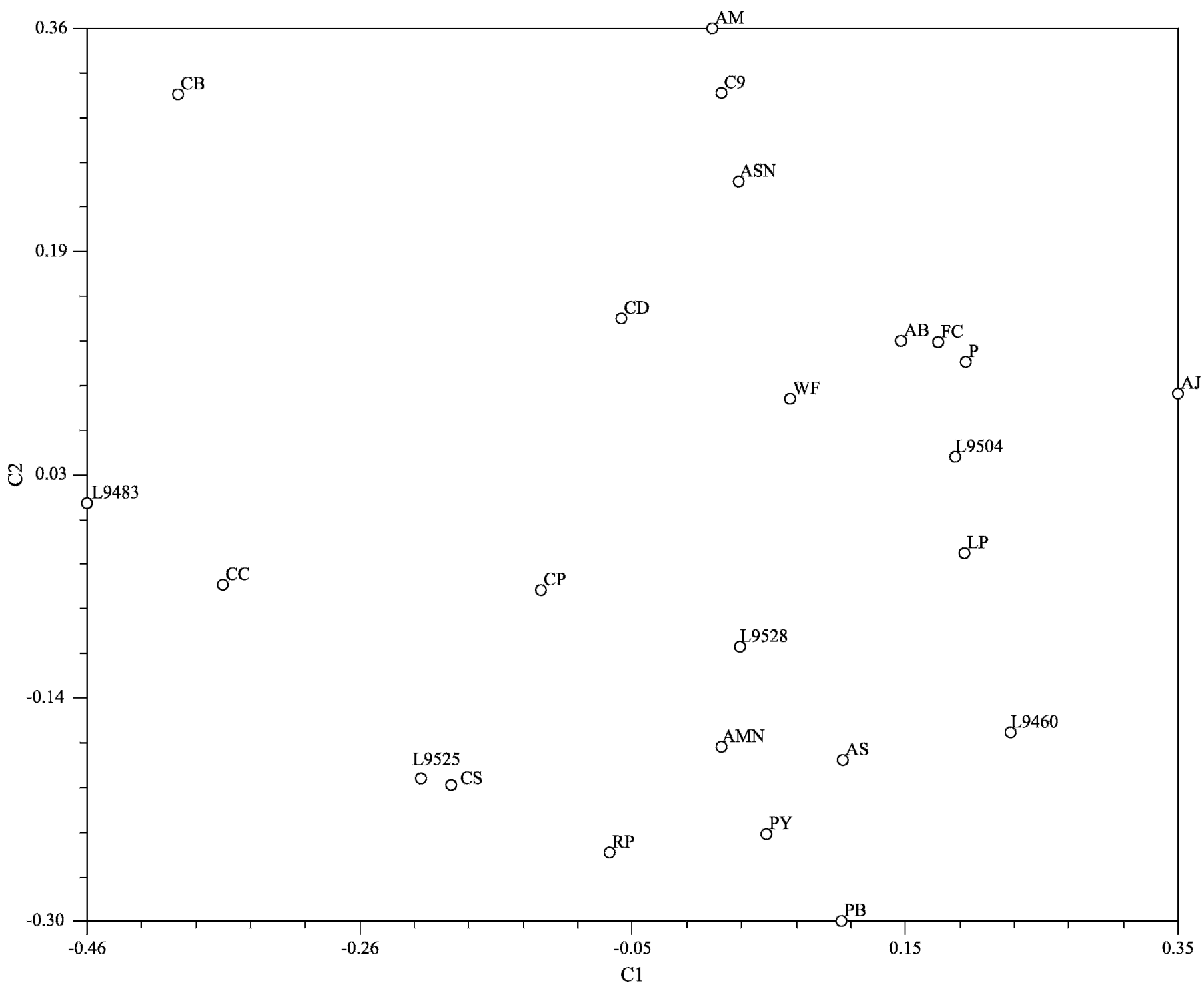

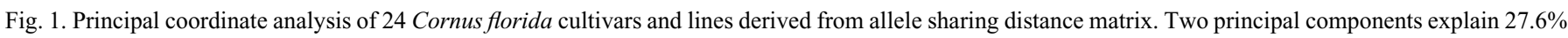
of total variation with the $\mathrm{x}$-axis explaining $14.5 \%$ of total variation and the $\mathrm{y}$-axis explaining $13.1 \%$ of total variation. $\mathrm{AB}=$ 'Appalachian $\mathrm{Blush}$ ', $\mathrm{AJ}=$ 'Appalachian Joy', AM = 'Appalachian Mist', AMN = 'Appalachian Morning', AS = 'Appalachian Spring', ASN = 'Appalachian Snow', CB = 'Cherokee Brave', $\mathrm{CC}=$ 'Cherokee Chief', $\mathrm{CD}=$ 'Cherokee Daybreak', $\mathrm{CP}=$ 'Cherokee Princess', $\mathrm{CS}=$ 'Cherokee Sunset', C9 = 'Cloud 9', FC = 'Fragrant Cloud', LP = 'Little Princess', P = 'Plena', PB = 'Presidential’, PY = 'Pygmy’, RP = ‘Red Pygmy', WF = ‘World’s Fair', L9460 = Line 94-60, L9483 = Line 94-83, L9504 = Line 95-04, L9525 = Line 95-25, L9528 = Line 95-28.

All 13 C. kousa SSR loci were polymorphic and four of these loci (CK005, CK029, CK031, and CK058) successfully amplified when tested on 22 cultivars of kousa dogwood. The other nine loci failed to amplify products in some of the 22 samples and these missing data were coded as null alleles for analysis. DNAs from the cultivars Big Apple, Blue Shadow, Milky Way Select, Steeple, and Trinity Star were amplified successfully with all 13 SSR loci, but the remaining 17 C. kousa cultivars had one or more null alleles. In total, 102 alleles were detected with a range of three to 17 per locus (Table 2). The allele sharing distance matrix and PCA for kousa dogwood demonstrated high genetic diversity for the loci analyzed. Allele sharing distances ranged from 0.41 to 1.00 and most of the values were greater than 0.80 (Table 5). Principal coordinate analysis based on allele sharing distances accounted for $28.9 \%$ of the total variation (Fig. 3) and no clusters of cultivars are discernible. Six loci (CK005, CK015, CK031, CK040, CK058, and CK072) were used to develop a molecular key that delineated all 22 of 22 kousa dogwood cultivars (Fig. 4).

\section{Discussion}

Dogwoods are obligate outcrossing species that are pollinated primarily by generalist insects and are considered selfsterile (Ament et al., 2000; Cappiello and Shadow, 2005; Gunatilleke and Gunatilleke, 1984; Orton, 1985; Reed, 2004; Sork et al., 2005; Witte et al., 2000). Most new cultivars of flowering and kousa dogwood arise from spontaneous mutations or bud sports from existing cultivars or from selections of open-pollinated seedlings exhibiting new ornamental traits (Cappiello and Shadow, 2005). Because outcrossing plant species tend to be heterozygous, this provides adequate genetic 


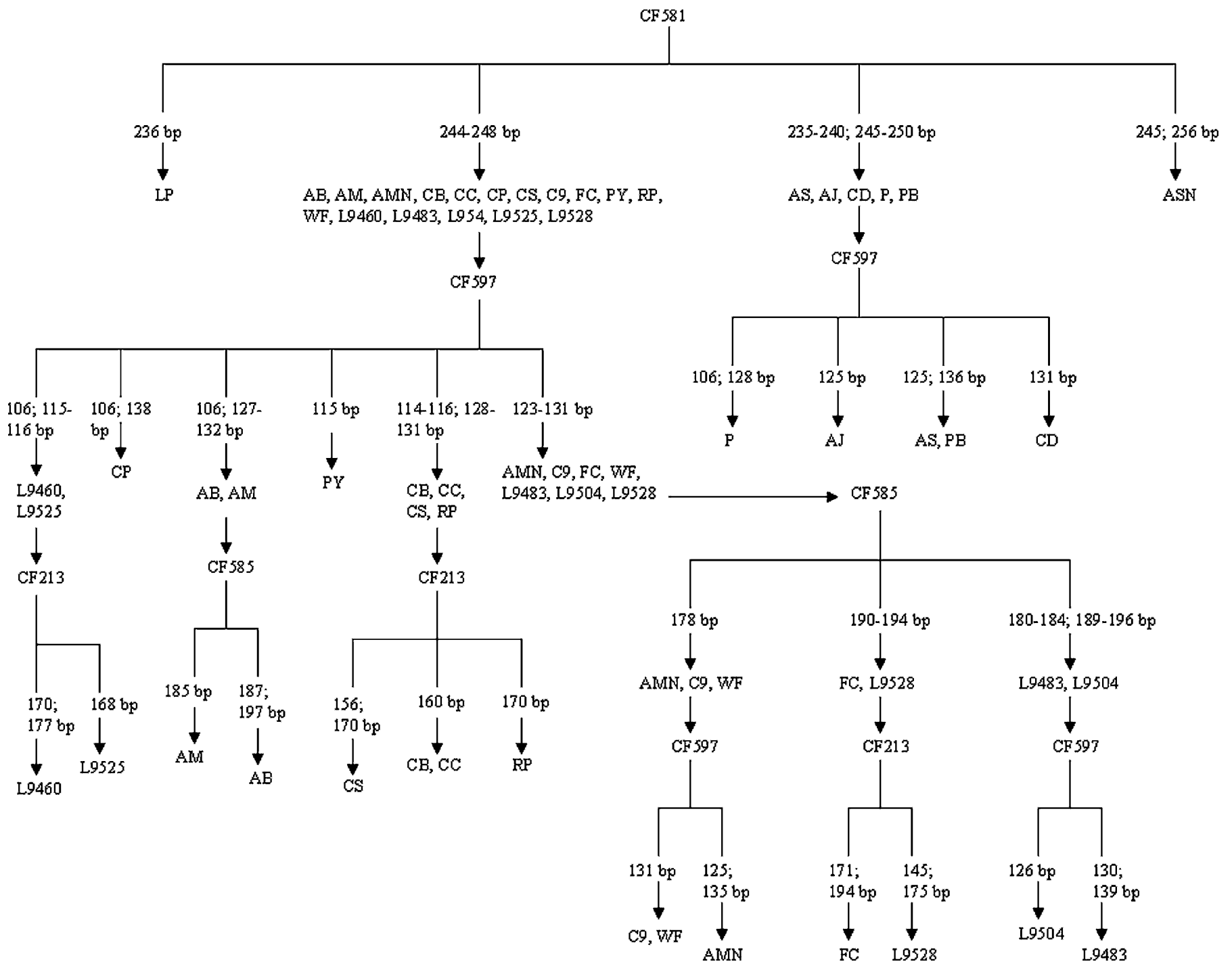

Fig. 2. Molecular key for 24 Cornus florida cultivars and lines based on simple sequence repeat (SSR) loci CF213, CF581, CF585, and CF597. AB = 'Appalachian Blush', AJ = 'Appalachian Joy', AM = 'Appalachian Mist', AMN = 'Appalachian Morning', AS = 'Appalachian Spring', ASN = 'Appalachian Snow', CB = 'Cherokee Brave', $\mathrm{CC}=$ 'Cherokee Chief', $\mathrm{CD}=$ 'Cherokee Daybreak', $\mathrm{CP}=$ 'Cherokee Princess', $\mathrm{CS}=$ 'Cherokee Sunset', $\mathrm{C} 9=$ 'Cloud 9', FC = 'Fragrant Cloud', LP = 'Little Princess', P = 'Plena', PB = 'Presidential', PY = 'Pygmy', RP = 'Red Pygmy', WF = ‘World's Fair', L9460 = Line 94-60, L9483 = Line 94-83, L9504 = Line 95-04, L9525 = Line 95-25, L9528 = Line 95-28.

variability for breeders to improve traits of interest. Most dogwood cultivars are clonally or vegetatively propagated to maintain the genotype. However, the phenotypes of most flowering and kousa dogwood cultivars are similar and practically indistinguishable until a juvenility phase is completed and bract characteristics can be observed. Molecular tools allow the identification of a specific genotype instead of identification based on limited phenotypic differences and will be increasingly useful not only for nurseries, breeders, and consumers, but also for genetic research.

Although the phenotype is generally similar for cultivars within either species, the genotypes based on molecular markers were expected to vary considerably among the cultivars within each species. Molecular techniques such as DAF, AFLP, and SSRs have been used to produce genetic fingerprints or DNA profiles for distinguishing horticultural cultivars of many species, including carnation (Dianthus caryophyllus) (Smulders et al., 2003; Trigiano and Caetano-Anollés, 1998), chrysanthemum (Dendranthema xgrandiflora) (Scott et al.,
1996; Trigiano et al., 1998), crape myrtle (Lagerstroemia indica and L. speciosa) (Pounders et al., 2007), various dogwoods (C. florida and C. kousa) (Ament et al., 2000; CaetanoAnollés et al., 1999; Smith et al., 2007; Trigiano et al., 2004; Windham and Trigiano, 1998), hydrangea (Hydrangea spp.)

Table 4. Similarity indices determined using DNA amplification fingerprinting between Cornus florida 'Appalachian Spring' (AS), 'Fragrant Cloud' (FC), ‘Appalachian Joy' (AJ), ‘Cloud Nine' (C9), and 'World's Fair' (WF)'.

\begin{tabular}{lccccc}
\hline & AS & FC & AJ & C9 & WF \\
\hline AS & 0.00 & & & & \\
FC & 0.47 & 0.00 & & & \\
AJ & 0.50 & 0.15 & 0.00 & & \\
C9 & 0.46 & 0.12 & 0.23 & 0.00 & \\
WF & 0.46 & 0.12 & 0.23 & 0.00 & 0.00
\end{tabular}

${ }^{\mathrm{Z}}$ Lower values indicate greater genetic similarity and higher values indicate greater genetic diversity between samples. 
Table 5. Allele sharing distance for Cornus kousa cultivars ${ }^{\mathrm{z}}$.

\begin{tabular}{|c|c|c|c|c|c|c|c|c|c|c|c|c|c|c|c|c|c|c|c|c|c|c|}
\hline & $\mathrm{AR}^{\mathrm{y}}$ & BF & $\mathrm{BA}$ & BS & B & $\mathrm{BP}$ & $\mathrm{D}$ & EL & $\mathrm{ES}$ & $\mathrm{G}$ & GS & MW & MWS & MS & $\mathrm{N}$ & $\mathrm{R}$ & SF & SP & ST & $\mathrm{SM}$ & $\mathrm{TJ}$ & $\mathrm{TS}$ \\
\hline$\overline{\mathrm{AR}^{\mathrm{y}}}$ & 0.00 & & & & & & & & & & & & & & & & & & & & & \\
\hline $\mathrm{BA}$ & 1.00 & 0.82 & 0.00 & & & & & & & & & & & & & & & & & & & \\
\hline B & 0.73 & 0.91 & 0.79 & 0.50 & 0.00 & & & & & & & & & & & & & & & & & \\
\hline BP & 1.00 & 0.78 & 0.90 & 0.80 & 0.80 & 0.00 & & & & & & & & & & & & & & & & \\
\hline D & 1.00 & 0.75 & 0.94 & 0.94 & 0.89 & 0.88 & 0.00 & & & & & & & & & & & & & & & \\
\hline G & 0.90 & 0.85 & 0.68 & 0.82 & 0.86 & 0.94 & 0.94 & 0.91 & 0.67 & 0.00 & & & & & & & & & & & & \\
\hline GS & 1.00 & 0.77 & 0.79 & 0.83 & 0.92 & 0.90 & 1.00 & 1.00 & 0.90 & 0.91 & 0.00 & & & & & & & & & & & \\
\hline MW & 0.91 & 0.86 & 0.83 & 0.79 & 0.79 & 0.90 & 0.94 & 0.83 & 0.80 & 0.59 & 0.75 & 0.00 & & & & & & & & & & \\
\hline MWS & 0.86 & 0.95 & 0.92 & 0.88 & 1.00 & 1.00 & 1.00 & 0.75 & 1.00 & 0.91 & 0.92 & 0.92 & 0.00 & & & & & & & & & \\
\hline MS & 0.91 & 0.86 & 0.75 & 0.83 & 0.83 & 0.80 & 1.00 & 0.92 & 0.70 & 0.73 & 0.88 & 0.63 & 0.92 & 0.00 & & & & & & & & \\
\hline ST & 1.00 & 0.77 & 0.77 & 0.77 & 0.92 & 0.90 & 0.67 & 0.83 & 0.90 & 0.91 & 0.83 & 0.83 & 0.96 & 0.88 & 0.75 & 0.50 & 0.67 & 0.67 & 0.00 & & & \\
\hline SM & 1.00 & 0.94 & 0.91 & 0.86 & 0.90 & 0.75 & 0.94 & 1.00 & 0.89 & 1.00 & 0.95 & 0.85 & 0.91 & 0.85 & 0.80 & 0.95 & 0.85 & 1.00 & 1.00 & 0.00 & & \\
\hline TJ & 0.91 & 0.86 & 0.67 & 0.67 & 0.71 & 0.75 & 0.89 & 0.71 & 0.65 & 0.82 & 0.92 & 0.83 & 0.92 & 0.83 & 0.79 & 0.64 & 0.58 & 0.58 & 0.75 & 0.90 & 0.00 & \\
\hline TS & 0.86 & 0.82 & 0.69 & 0.50 & 0.63 & 0.85 & 0.94 & 0.75 & 0.60 & 0.73 & 0.92 & 0.67 & 0.81 & 0.88 & 0.71 & 0.71 & 0.67 & 0.67 & 0.85 & 0.82 & 0.63 & 0.00 \\
\hline
\end{tabular}

${ }^{\mathrm{z}}$ Lower values indicate greater genetic similarity and higher values indicate greater genetic diversity between samples.

${ }^{\mathrm{y}} \mathrm{AR}=$ 'Autumn Rose', BF = 'Beni Fuji', BA = 'Big Apple', B = 'Bodnant', BP = 'Bush's Pink', D = 'Doubloon', EL = 'Elizabeth Lustgarten', $\mathrm{ES}=$ 'Emerald Star', G = 'Galilean', GS = 'Greensleeves', MW = 'Milky Way', MWS = 'Milky Way Select', MS = 'Miss Satomi', N = 'National', $\mathrm{R}=$ 'Rochester', $\mathrm{SF}=$ 'Snow Flake', SP = 'Spinners', ST = 'Steeple', SM = 'Summer Majesty', TJ = 'Temple Jewel', TS = 'Trinity Star'.

(Reed and Rinehart, 2007; Rinehart et al., 2006), pampas grass (Cortaderia selloana) (Ahmad et al., 2006), and pelargonium (Pelargonium spp.) (Becher et al., 2001).

In our study, SSRs were used to assess genetic diversity of 24 flowering dogwood cultivars and breeding lines and 22 kousa dogwood cultivars. As expected for an outcrossing species, genetic diversity was high. Most allele sharing distances were greater than 0.70 for the flowering dogwood cultivars and breeding lines. Kousa dogwood cultivars exhibited higher allele sharing distance with some values greater than 0.90 . Additionally, PCA supported the assessment of high genetic diversity because there were no discernible clusters and two principal coordinates explained less than $29 \%$ of total variation. It was recently noted that 'Cherokee Brave' and 'Cherokee Sunset' are open-pollinated seedling selections of 'Cherokee Chief' and these cultivars are expected to be more closely related (Smith et al., 2007). The pairwise comparison allele sharing distance values of these three cultivars were 0.50 , indicating lower genetic diversity than the other flowering dogwood cultivars and breeding lines tested.

We developed two molecular keys, one for flowering dogwood and one for kousa dogwood cultivars, using four SSR loci and six SSR loci, respectively. These keys distinguished most of the flowering dogwood cultivars and breeding lines and all kousa dogwood cultivars. However, the molecular keys for flowering dogwood failed to separate 'Cherokee Brave' from 'Cherokee Chief', 'Appalachian Spring' from 'Presidential', and 'Cloud 9' from 'World's Fair'. CaetanoAnollés et al. (1999) used DAF to uniquely identify 'Cherokee Brave' from 'Cherokee Chief', and we applied the same methods to discern 'Cloud 9' from 'World's Fair'. DAF was unable to discern 'Cloud 9' from 'World's Fair' and this can be explained in two ways, either the trees we used were mislabeled or the two cultivars are actually the same genetically but are sold under two different names. 'Appalachian Spring' and 'Presidential' were unable to be distinguished by the key because 'Appalachian Spring' was cloned from the cultivar initially named 'Presidential' (Caetano-Anollés et al., 1999).

The discrepancy in both allele sharing distance and cultivar identification can be explained by the limited resolution of eGene that can lead to allele size determination difficulties. The manufacturer's program lists the resolution of amplified PCR products (alleles) to be 2 to $5 \mathrm{bp}$ among samples, but the software used to develop the allele sharing distance matrix uses 1-bp size differences in allele size calling. This problem leads to an inflation in the number of different alleles detected and explains why the allele sharing distance for the undistinguished cultivars is 0.50 for the flowering dogwood samples and 0.44 for the kousa dogwood samples. When 4 to $6 \mathrm{bp}( \pm 2$ - to 3-bp error range) was used as the maximum resolution for allele size calling, allele sizes for 'Cherokee Brave' and 'Cherokee Chief', 'Appalachian Spring' and 'Presidential', and 'Cloud 9' and 'World's Fair' are the same and the allele sharing distances between the cultivars is zero, indicating genetic identity between the pairs (data not shown). Because our molecular key failed to separate six flowering dogwood cultivars, DAF was used to distinguish 'Cherokee Brave' and 'Cherokee Chief' but could not distinguish 'Cloud 9' and 'World's Fair' (data not shown). One technical problem with SSRs is comparing data produced by different laboratories as a result of the inconsistencies in allele size calling. Such inconsistencies in allele size calling are mainly the result of the large variety of automatic sequencing machines used, each providing different gel migration, fluorescent dyes, allele calling software used, 


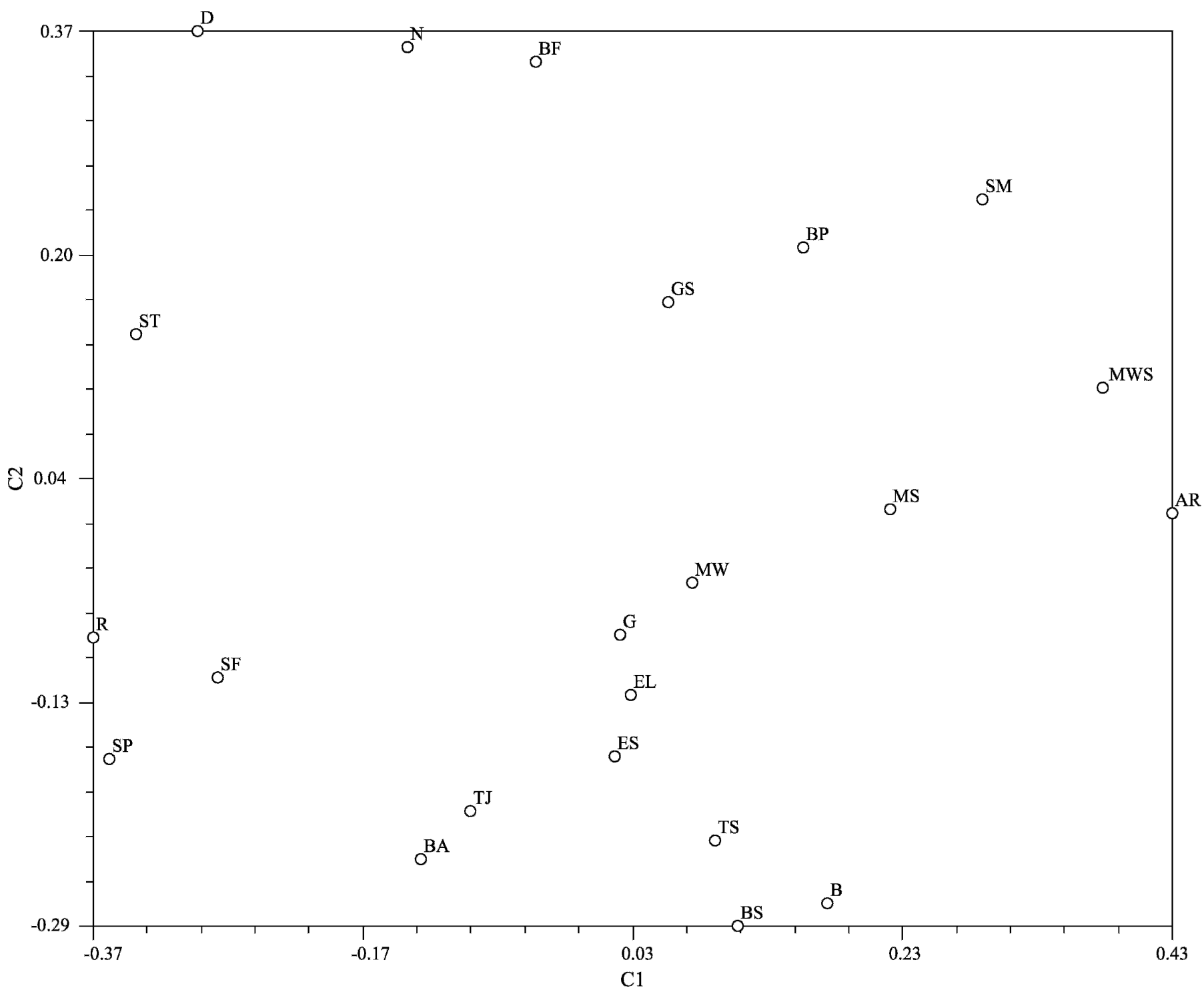

Fig. 3. Principal coordinate analysis of 22 Cornus kousa cultivars derived from allele sharing distance matrix. Two principal components explain $28.9 \%$ of total variation with the $\mathrm{x}$-axis explaining $15.5 \%$ of total variation and the $\mathrm{y}$-axis explaining $13.4 \%$ of total variation. $\mathrm{AR}=$ 'Autumn Rose', $\mathrm{BF}=$ ' $\mathrm{Beni}$ Fuji', $\mathrm{BA}=$ ' $\mathrm{Big}$ Apple', B = 'Bodnant', BP = 'Bush's Pink', D = 'Doubloon', EL = 'Elizabeth Lustgarten', ES = 'Emerald Star', G = 'Galilean', GS = 'Greensleeves', MW = 'Milky Way', MWS = 'Milky Way Select', MS = 'Miss Satomi', N = 'National', R = 'Rochester', SF = 'Snow Flake', SP = 'Spinners', ST = 'Steeple', SM = 'Summer Majesty', TJ = 'Temple Jewel', TS = 'Trinity Star'.

and conditions of the PCR reaction (Semagn et al., 2006). Considering eGene's limited resolution and the various experimental conditions that can vary among laboratories using similar electrophoretic systems, we conservatively used a resolution of 4 to $6 \mathrm{bp}$ in allele size calling for the development of both molecular keys. When the conservative 4- to 6-bp allele size calling was applied to the flowering dogwood cultivars and breeding lines, the molecular key failed to distinguish all samples and the allele sharing distances indicated that the cultivars in question are similar (data not shown).

The Plant Patent Act was adopted in the United States in 1930 and is limited to asexually propagated plants (Aguirre, 2006). Koo et al. (2004) compiled and summarized data from 1930 to 2003 for plant patents and plant variety protection applications and indicated that over $50 \%$ of the applications in the United States were for protection of ornamentals rather than food crops. Combined sales of ornamentals exceeds $\$ 8$ billion dollars, which supports Aguirre's (2006) claim that the breeding and commercialization of new ornamental plant varieties is an economically important activity both for the industry and the well-being of our society. Mislabeling of cultivars affects breeding progress and the nursery industry. Aguirre (2006) also notes how important it is that both breeders and companies introducing new plants ensure that protection information is correct and that there is a need for catalogs, tags, and other marketing material to be monitored. Molecular tools used to develop genetic fingerprints will help breeders and nurseries to uniquely identify plants by genotype and can be important in obtaining a plant patent or prosecuting infringement. The molecular key for flowering and kousa dogwood cultivars and/or breeding lines may help nursery growers to identify different dogwood cultivars when the phenotypes are very similar. Additionally, the genetic diversity estimates and 


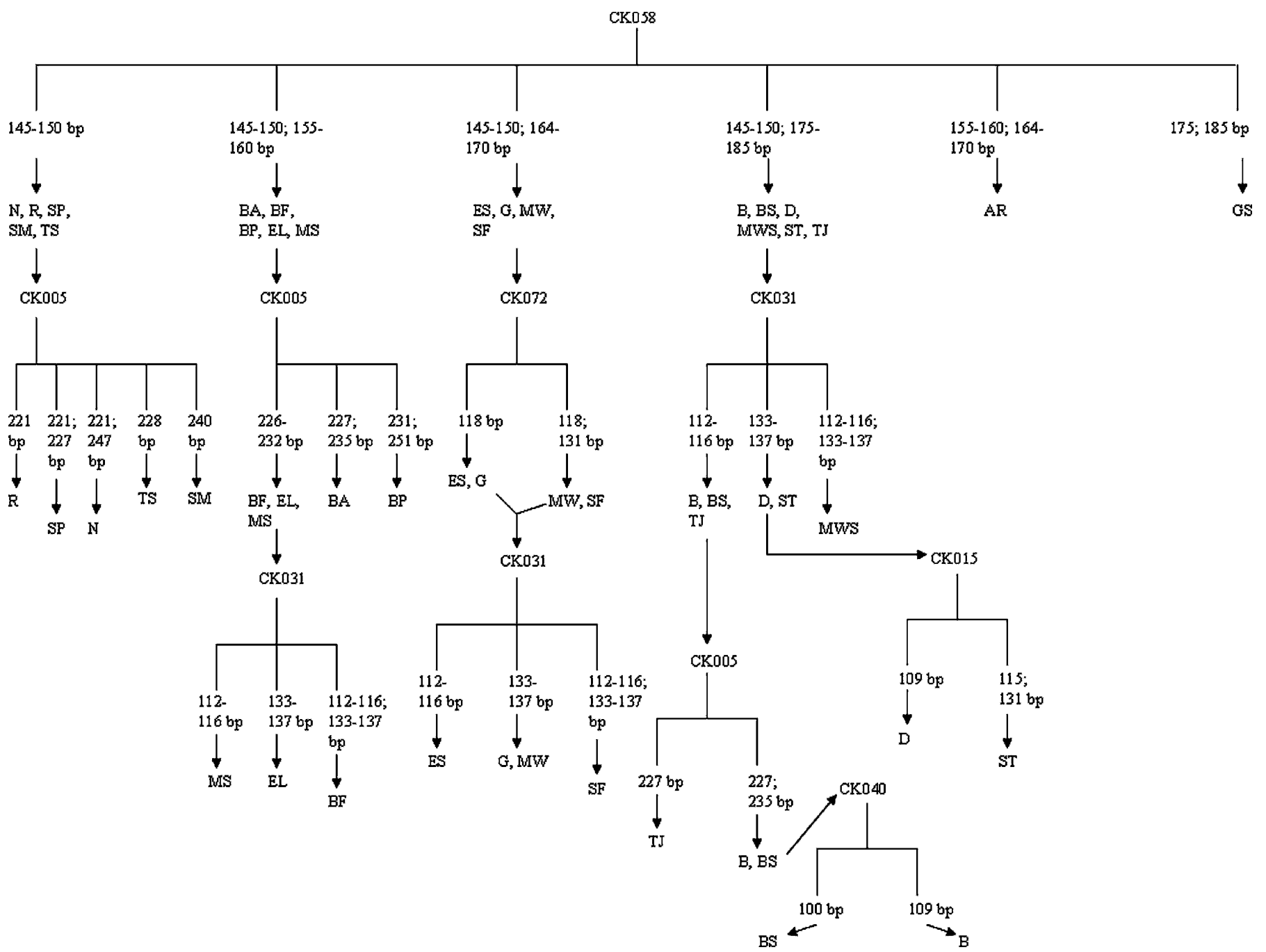

Fig. 4. Molecular key for 22 Cornus kousa cultivars based on simple sequence repeat (SSR) loci CK005, CK015, CK031, CK040, CK058, and CK072. $\mathrm{AR}=$ 'Autumn Rose', $\mathrm{BF}=$ 'Beni Fuji', BA = 'Big Apple', $\mathrm{B}=$ 'Bodnant', $\mathrm{BP}=$ ='Bush's Pink', $\mathrm{D}=$ 'Doubloon', EL = 'Elizabeth Lustgarten', ES = 'Emerald Star', $\mathrm{G}=$ 'Galilean', GS = 'Greensleeves', MW = 'Milky Way', MWS = 'Milky Way Select', MS = 'Miss Satomi', N = 'National', R = 'Rochester', SF = 'Snow Flake', $\mathrm{SP}=$ 'Spinners', $\mathrm{ST}=$ 'Steeple', $\mathrm{SM}=$ 'Summer Majesty', TJ = 'Temple Jewel', TS = 'Trinity Star'.

molecular keys provide evidence to plant breeders for parental analysis, marker-assisted breeding, and genome linkage mapping.

\section{Literature Cited}

Aguirre, P. 2006. Protection: Plant patents, utility patents, plant breeders' rights, trademarks, branding, royalties, p. 81-112. In: Anderson, N.O. (ed.). Flower breeding and genetics. SpringerVerlag, New York, NY.

Ahmad, R., M. Okada, J.L. Firestone, C.R. Mallek, and M. Jasieniuk. 2006. Isolation, characterization, and evaluation of microsatellite loci for cultivar identification in the ornamental pampas grass Cortaderia selloana. J. Amer. Soc. Hort. Sci. 131:499-505.

Ament, M.H., M.T. Windham, and R.N. Trigiano. 2000. Determination of parentage of flowering dogwood (Cornus florida) seedlings using DNA amplification fingerprinting. J. Arboriculture 26:206212.

Arus, P. 2000. Molecular markers for ornamental breeding. Acta Hort. 508:91-98.

Bassam, B.J., G. Cetano-Anollés, and P.M. Gresshoff. 1991. Fast and sensitive silver staining of DNA in polyacrylamide gels. Anal. Biochem. 196:80-83.
Becher, S.A., K. Steinmetz, K. Weising, S. Boury, D. Peltier, J.P. Renou, G. Kahl, and K. Wolff. 2001. Microsatellites for cultivar identification in Pelargonium. Theor. Appl. Genet. 101:643-651.

Caetano-Anollés, G., B.J. Bassam, and P.M. Gresshoff. 1991. DNA amplification fingerprinting using very short arbitrary oligonucleotide primers. Bio/Technology 9:553-557.

Caetano-Anollés, G., S.S. Schlarbaum, and R.N. Trigiano. 1999. DNA amplification fingerprinting and marker screening for pseudotestcross mapping in flowering dogwood (Cornus florida L.). Euphytica 106:209-222.

Cappiello, P. and D. Shadow. 2005. Dogwoods. Timber Press, Portland, OR.

Dirr, M.A. 1998. Manual of woody landscape plants. 5th Ed. Stipes Publishing, Champaign, IL.

Fan, C. and Q. Xiang. 2001. Phylogenetic relationships within Cornus (Cornaceae) based on 26S rDNA sequences. Amer. J. Bot. 88:11311138.

Gunatilleke, C.V.S. and I.A.U.N. Gunatilleke. 1984. Some observations on the reproductive biology of three species of Cornus (Cornaceae). J. Arnold Arbor. 65:419-427.

Hagan, A.K., C.H. Gilliam, G.J. Keever, R.B. Hardin, J.D. Eakes, and J.D. Williams. 2001. Disease resistance and adaptability of 
flowering, kousa and hybrid dogwood in Alabama. Alabama Agr. Expt. Sta. Bul. No. 642.

Jin, L. and R. Chakraborty. 1994. Estimation of genetic distance and coefficient of gene diversity from single probe multilocus DNA fingerprint data. Mol. Biol. Evol. 11:120-127.

Koo, B., C. Nottenburg, and P.G. Pardey. 2004. Plants and intellectual property: An international appraisal. Science 304:1295-1297.

Langella, O. 2002. Populations: Population genetic software (individuals or populations distances, phylogentic trees). 8 Feb. 2008. $<$ http://www.bioinformatics.org/project/?group_id=84>.

Orton E.R.,, Jr. 1985. Interspecific hybridization among Cornus florida, C. kousa, and C. nutallii. Proc. Intl. Plant Prop. Soc. 35: 655-661.

Pejic, I., P. Ajmone-Marsan, M. Morgante, V. Kozumplick, P. Castaglioni, G. Taramino, and M. Motto. 1998. Comparative analysis of genetic similarity among maize inbred lines detected by RFLPs, RAPDs, SSRs and AFLPs. Theor. Appl. Genet. 97:12481255.

Pounders, C., T. Rinehart, and H. Sakhanokho. 2007. Evaluation of interspecific hybrids of Lagerstroemia indica and L. speciosa. HortScience 42:1317-1322.

Powell, W., G.C. Machray, and J. Provan. 1996. Polymorphism revealed by simple sequence repeats. Trends Plant Sci. 1:215-222.

Ranney, T.G., L.F. Grand, and J.L. Knighten. 1995. Susceptibility of Cornus kousa cultivars and hybrids to dogwood anthracnose and powdery mildew. J. Arboriculture 21:11-16.

Reed, S.M. 2004. Self-incompatibility in Cornus florida. HortScience 39:335-338.

Reed, S.M. and T.A. Rinehart. 2007. Simple sequence repeat marker analysis of genetic relationships within Hydrangea macrophylla. J. Amer. Soc. Hort. Sci. 132:141-151.

Rinehart, T.A., B.E. Scheffler, and S.M. Reed. 2006. Genetic diversity estimates for the genus Hydrangea and development of a molecular key based on SSR. 2006. J. Amer. Soc. Hort. Sci. 131:787-797.

Rohlf, F.J. 1992. NTSYS-pc numerical taxonomy and multivariate analysis system. Version 1.70. Exeter Software, Setauket, NY.

Scott, M.C., G. Caetano-Anollés, and R.N. Trigiano. 1996. DNA amplification fingerprinting identifies closely related chrysanthemum cultivars. J. Amer. Soc. Hort. Sci. 121:1043-1048.

Semagn, K., A. Bjornstad, and M.N. Ndjiondjop. 2006. An overview of molecular marker methods for plants. Afr. J. Biotechnol. 5:2540 2568 .
Smith, R.S., R.N. Trigiano, M.T. Windham, K.H. Lamour, L.S. Finley, and X. Wang. 2007. AFLP markers identify Cornus florida cultivars and lines. J. Amer. Soc. Hort. Sci. 132:90-96.

Smulders, M.J.M., Y. Noordijk, W. Rus-Kortekaas, G.M.M. Bredemeijer, and B. Vosman. 2003. Microsatellite genotyping of carnation varieties. Theor. Appl. Genet. 106:1191-1195.

Sork, V.L., P.E. Smouse, V.J. Apsit, R.J. Dyer, and R.D. Westfall. 2005. A two-generation analysis of pollen pool genetic structure in flowering dogwood, Cornus florida (Cornaceae), in the Missouri Ozarks. Amer. J. Bot. 92:262-271.

Trigiano, R.N., M.H. Ament, M.T. Windham, and J.K. Moulton. 2004. Genetic profiling of red-bracted Cornus kousa cultivars indicates significant cultivar synonomy. HortScience 39:489-492.

Trigiano, R.N. and G. Caetano-Anollés. 1998. Laboratory exercises on DNA amplification fingerprinting for evaluating the molecular diversity of horticultural species. HortTechnology 8:413-423.

Trigiano, R.N., M.C. Scott, and G. Caetano-Anollés. 1998. Genetic signatures from amplification profiles characterize DNA mutation in somatic and radiation-induced sports of chrysanthemum. J. Amer. Soc. Hort. Sci. 123:642-646.

U.S. Department of Agriculture. 1998. 1998 Census of horticultural specialties. U.S. Dept. Agr., Washington, DC.

U.S. Department of Agriculture. 2007. Nursery crops 2006 summary. U.S. Dept. Agr., Washington, DC.

Wadl, P.A., X. Wang, B.E. Scheffler, T.A. Rinehart, and R.N. Trigiano. 2008. Microsatellites from kousa dogwood (Cornus kousa). Mol. Ecol. Resources 8:780-782.

Wang, X., R. Trigiano, M. Windham, B. Scheffler, T. Rinehart, and J. Spiers. 2008. Development and characterization of simple sequence repeats for flowering dogwood (Cornus florida L.). Tree Genet. Genomes 4:461-468.

Windham, M.T. and R.N. Trigiano. 1998. Are 'Barton' and 'Cloud 9' the same cultivar of flowering dogwood? J. Environ. Hort. 16:163166.

Winter, P., B. Huttel, K. Weising, and G. Kahl. 2002. Microsatellites and molecular breeding: Exploitation of microsatellite variability for the analysis of a monotonous genome, p. 85-138. In: Jain, S.M., D.S. Brar, and B.S. Ahloowalia (eds.). Molecular techniques in crop improvement. Springer-Verlag, New York, NY.

Witte, W.T, M.T. Windham, A.S. Windham, F.A. Hale, D.C. Fare, and W.K. Clatterbuck. 2000. Dogwoods for American gardens. Univ. Tennessee Agr. Ext. Serv. PB1670. 